\title{
Challenges in the Management of IBS Construction Projects
}

\author{
Izatul Laili Jabar, Faridah Ismail \\ Faculty of Architecture, Planning \& Surveying, \\ Universiti Teknologi MARA, Shah Alam, Selangor, Malaysia \\ izatul_laili@salam.uitm.edu.my
}

\begin{abstract}
IBS application had claimed to offer a faster construction, high quality, cost saving, cleaner and safer construction site. However, several challenges in management during the construction phase had been identified by researchers. This paper aims to analyze the challenges and issues arise in managing IBS construction projects. The challenges and issues identified can be categorized into pre-construction, construction and post-construction phases. Categorizing the challenges and issues will help to increase the contractor's understanding and help them to be prepared in handling the situation that they may encounter during the project phases.

Keywords: Issues, construction phases, construction process, project management.

eISSN 2398-4279 @ 2018. The Authors. Published for AMER ABRA cE-Bs by e-International Publishing House, Ltd., UK. This is an open access article under the CC BY-NC-ND license (http://creativecommons.org/licenses/bync-nd/4.0/). Peer-review under responsibility of AMER (Association of Malaysian Environment-Behaviour Researchers), ABRA (Association of Behavioural Researchers on Asians) and $c E-B s$ (Centre for EnvironmentBehaviour Studies), Faculty of Architecture, Planning \& Surveying, Universiti Teknologi MARA, Malaysia.

DOI: https://doi.org/10.21834/ajqol.v3i9.75
\end{abstract}




\subsection{Introduction}

The adoption of Industiralised Building System (IBS) in the construction industry does have apparent and numerous benefits to the industry players. These benefits set up as driving forces to the industry in deciding whether to use IBS or not (Pan et. al., 2007). Essentially, IBS can be defined as a process of producing building components in a large-scale production either on or off-site, transported or erected into a structure at the site with a minimum site work. However, despite the promotion of rigorous benefits in IBS adoption, industry stakeholders are still skeptical about the IBS usage since issues such as technical difficulties, design conflicts and skill shortages during the construction phase becoming the challenges.

Accordingly, in addressing a knowledge gap in construction level, this paper analyzes the challenges in managing the IBS projects that reflect IBS as a non efficient application in gaining its benefits. The identified challenges are expected to provide a better understanding and a clearer picture of the problems that may arise during the implementation of IBS project

\subsection{Literature Review}

\section{Advantages of Adopting IBS}

The advantages of adopting IBS are identified as follows:

\subsection{Cost and financial advantages}

Even the initial capital cost of adopting IBS construction is high, but this challenge normally off set by earlier completion time and resulted to the benefit of cost savings. Alinaitwe et. al., 2011). The use of system formwork made of steel, aluminium, scaffolding and etc. which can be used repetitively also provides considerable cost savings ( Thanoon et. al., 2003). IBS offers better cash flows to the developers as they can claim to the purchasers as early as two weeks upon erection of the building (Nawi et. al., 2007). Further, under controlled environment prefabrication method lead to less material wastages and usage of building material which means cost savings (Idrus et. al., 2008).

\subsection{Construction speed}

IBS allows fasters completion time or reduce build time as compared to conventional method (Thanoon et. al., 2003). This is because, the speed of IBS construction process is governed by the speed of production and controlled environment of manufacturing facilities (Aburas, 2011) , thus the need on fast delivery can easily be met by increasing the production capacity (Nawi et. al., 2007).

\subsection{Reducing labour}

Since IBS component manufactured in centralised factory, thus, automatically its reduced the labour requirement at construction site (Warszawski, 1999).

\subsection{Better quality}

Alinaitwe et. al., (2011) mentions that the industrialisation process lead to improved quality products in view of the fact that the production is under control condition. This opinion support the earlier statement by Thanoon et. al., (2003) describing IBS components are of higher 
quality since it is produced through careful selection of materials, use of advanced technology, strict quality assurance control and is not affected by adverse weather condition. Further, the need of using skilled workers in assembly process of IBS components ensuring better construction quality (Kamar et. al., 2010).

\subsection{Health and safety measures}

IBS application will improve site safety by providing cleaner and tidier site environment,( Tam et. al.2007) . At the same time, IBS usage will minimise site activities, indirectly it will reduce construction hazards leading to improvement of worker's safety and health (Alinaitwe et. al., 2011).

\subsection{Flexibility}

Warszawski, (1999) in the opinion that in order to minimise uniformity of repetitive facades, IBS allows flexibility in architectural design. Simultaneously, the flexibility of different system used in IBS construction process produced own unique prefabrication method (Thanoon et. al., 2003).

\subsection{Waste minimization}

The production of IBS components in factory under control environment had resulted to less wastage of materials which also will lead to cost savings (Kamar et. al., 2010). At the same time, factory production encourage recycling construction waste, leading to environmental protection and sustainability of the industry (Tam et. al., 2007).

\subsection{Improving productivity}

Kadir et. al., (2005) indentified the factor which reduce the productivity of contractors in executing construction project is lack of foreign and local workers in the market. Thus, by adopting IBS component in construction projects, this issue can be overcome since IBS construction required less workers.

\section{Generic challenges in managing IBS in Construction Projects}

Researchers had highlighted several challenges, which led to the government's target in IBS application, are beyond the anticipated level (Pan et. al.,2012; Nawi et. al., 2011). To what extent the full benefits of IBS materialization in the construction industry is unknown. Summarize in Table 1 below listed generic challenges in managing IBS construction projects.

Table 1: Challenges in Managing IBS Construction Projects

\begin{tabular}{|c|c|}
\hline Challenges & Descriptions \\
\hline $\begin{array}{l}\text { Enormous } \\
\text { capital cost }\end{array}$ & $\begin{array}{l}\text { Higher capital cost due to: } \\
\text { - Great investment is needed at the beginning to set up the } \\
\text { plant, supplying machinery and moulds and engineering } \\
\text { consideration (Qays et al., 2010) } \\
\text { - Require a huge volume of work to break even on the } \\
\text { investment which means IBS needs mass production in } \\
\text { order to achieve economic viability (Alinaitwe et al., 2011) } \\
\text { - Maintenance allocation for machineries }\end{array}$ \\
\hline
\end{tabular}




\begin{tabular}{|c|c|}
\hline & $\begin{array}{l}\text { - } \quad \text { Facing the inconsistency of volume demand } \\
\text { - Lower classes contractors usually do not have sufficient } \\
\text { funding to start adopting IBS (Sadafi et al., 2011). }\end{array}$ \\
\hline Human barriers & 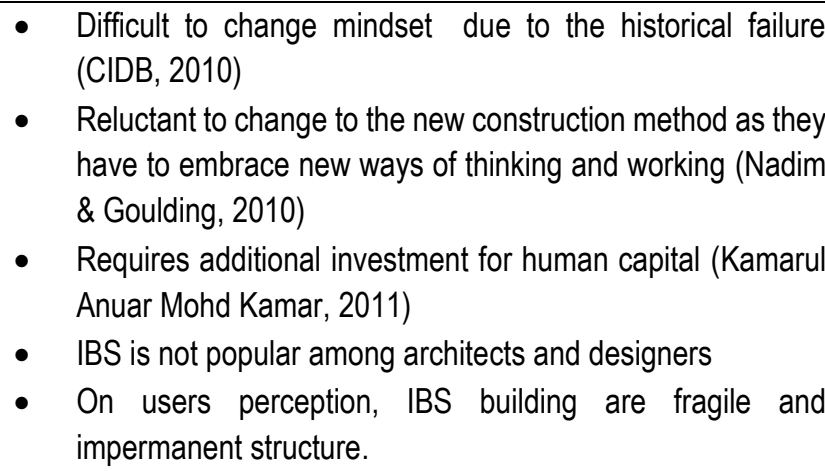 \\
\hline $\begin{array}{l}\text { Insufficient } \\
\text { knowledge }\end{array}$ & $\begin{array}{l}\text { - Lack of knowledge and exposure to IBS contributed to poor } \\
\text { structural analysis and design which leads to problems such } \\
\text { as cracks, leakage and other defects (Rahman \& Omar, } \\
\text { 2006) } \\
\text { - The lack of knowledge of the consultants, client/owner of the } \\
\text { project and the contractors is one of the reasons on delay } \\
\text { of IBS take-up (Onyeizu et al., 2011). } \\
\text { - Lack of educational courses in universities' academic } \\
\text { curricular had caused the industry players tend to choose } \\
\text { familiar conventional construction method (Qays et al., } \\
\text { 2010) }\end{array}$ \\
\hline $\begin{array}{l}\text { Component } \\
\text { standardisation } \\
\text { issue }\end{array}$ & $\begin{array}{l}\text { - The successful of IBS usage also depends on the } \\
\text { standardisation of components, to date the component } \\
\text { standardisation is perceived to be low which prevent the } \\
\text { same components to be used for other projects (Hashim \& } \\
\text { Kamar, 2011). } \\
\text { - The effect of low standardisation will increase the initial } \\
\text { cost due to the design cost and moulding which cannot be } \\
\text { used for other project (Hamid et al., 2008). }\end{array}$ \\
\hline $\begin{array}{l}\text { Availability of } \\
\text { cheap foreign } \\
\text { labour }\end{array}$ & $\begin{array}{l}\text { - Since the low labour rates can easily obtain, the contractors } \\
\text { are hesitate to move into other construction method } \\
\text { solutions which require higher capital cost and make IBS }\end{array}$ \\
\hline
\end{tabular}




\begin{tabular}{|c|c|}
\hline & $\begin{array}{l}\text { investment more risky. (Hashim \& Kamar, 2011) (Idrus et al., } \\
\text { 2008). (Warszawski, 1999). } \\
\text { This situation worsened by some irresponsible contractors } \\
\text { whom hired illegal foreign workers which indeed can be } \\
\text { acquired at a very low rates (Kamarul Anuar Mohd Kamar, } \\
\text { 2011). }\end{array}$ \\
\hline Transportation & $\begin{array}{l}\text { Challenges in transporting and coordinating IBS construction are: } \\
\text { - Size and weight limitations, route restrictions, permitting and } \\
\text { the availability of lifting equipment Haas \& Fagerlund, (2002) } \\
\text { - Additional lift planning is required when the components } \\
\text { reach the construction site } \\
\text { - The complexity of lift normally increases with the increase in } \\
\text { level of IBS usage }\end{array}$ \\
\hline Coordination & $\begin{array}{l}\text { - Coordination of design, transportation, tracking, and } \\
\text { installation to ensure successful implementation. } \\
\text { - Apart from that, the work breakdown structure, terminology, } \\
\text { drawings, progress measurement, scheduling for materials } \\
\text { management and supply chain scheduling should also take } \\
\text { into consideration. } \\
\text { - With the increased of coordination, effective communication } \\
\text { becoming vital for the distribution of information regarding } \\
\text { decisions, designs, transportation requirements and } \\
\text { schedules. }\end{array}$ \\
\hline $\begin{array}{l}\text { On-site } \\
\text { construction } \\
\text { process issue }\end{array}$ & $\begin{array}{l}\text { - The IBS components such as concrete panels are generally } \\
\text { heavy and difficult to align which may lead to the problem of } \\
\text { improper assembly, leakage and crack in the future } \\
\text { (Rahman \& Omar, 2006). } \\
\text { - Site specifics or contraints also caused problems to the IBS } \\
\text { construction process since IBS components required extra } \\
\text { space for storage, mobilisation and circulation of } \\
\text { mechineries and equipments }\end{array}$ \\
\hline
\end{tabular}

\subsection{Methodology}

The examination is through a critical review of available relevant literature on the system from various books and article. This study reviewed 50 existing literatures on IBS. The reviewed does not limit to articles published in the peer-reviewed journals, but also includes theses 
and books. In order to develop new findings, the limit of this research is from the year 2000 to 2014.

\subsection{Findings and Analysis}

Poor management of IBS projects often led to many difficulties, which end up to project delays, unacceptable qualities and higher cost (Kamar et. al., 2009). The success of IBS implementation in the Malaysian construction industry is solely depending on the contractors who manage the processes involved in the IBS life cycle (Kamar, 2011). Apart from that, the commitment of contractor in managing the project is crucial to achieve maximum safety of that project (Ismail et. al., 2012). The contractor should be competent and experienced in managing the construction activities (Lou and Kamar, 2012). Similarly, the contractor should take into consideration all the challenges in their management practice in order to achieve success in the implementation of IBS projects.

Literatures have identified 28 challenges commonly arises in managing IBS construction projects. The identified challenges are divided into 3 construction phases as illustrated in Figure 1 below:

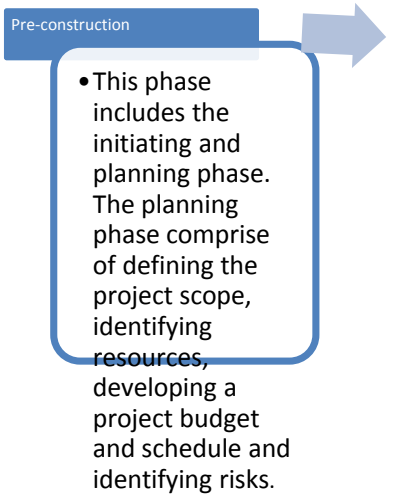

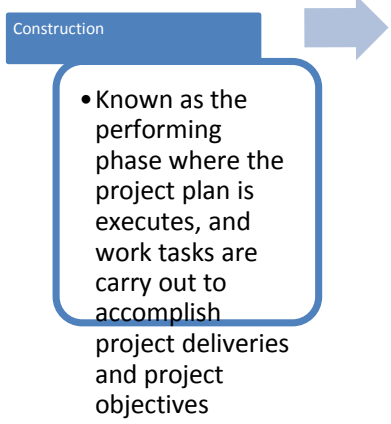

Figure 1: Construction phase

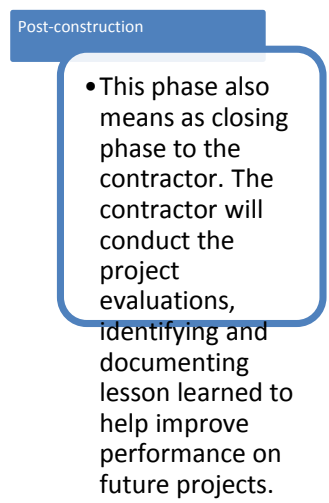

future projects.

The discussion of these challenges is to initiate more understanding for a contractor in managing IBS projects as per categorizations as follows:

\subsection{Pre-construction phase}

A major challenge in this phase is the initial capital cost which contractor needs to allocate and appropriately organize. The contractor is required to consider for investment of specialized equipment and machineries, training for human resources, transportation process, setting up prefabrication yard and etc. (Jaillon and Poon, 2009; Nawi et. al., 2011; Qays et. al., 2010). Such investment needs large volume of work to break even (Hamid et. 
al., 2011). In the other words, it only can be achieved if there is a continuing demand for the product (Thanoon et. al., 2003). Despite the requirement to convert a conventional drawing into IBS drawing, which, will consume time, the process employed to construct facility will also influence the project duration (Azman et. al., 2011)

As mentioned by Hamid et. al., (2007) lack of knowledge in relation to the building materials and installation methods together with no standard design or guidelines on the systems has led to the low quality of final products. Other challenges in this phase are lack of integration between project team, one of the problems here is there was no early involvement of the contractor, the contractor usually involved after the design phase, which makes them unable to contribute their opinion on the design and construction aspect of the system (Shukor et. al.,2011). IBS needs a systematic planning throughout the project lifecycle in terms of design, manufacturing, assembly and other related process which generally regards as difficult by the contractors due to the nature of the construction industry, which, is fragmented, diverse and involve many parties (Kamar, 2011). Poor planning will reduce the contractor productivity and slow down the construction process (Hassim et. al., 2009).

\subsection{Construction phase}

As the aim of IBS implementation is to reduce the dependency of unskilled foreign workers, subsequently, IBS required specialist skill workers to accomplish the installation process which depends more on machine oriented skills (Hamid et. al., 2008). However, most of the available skill workers are still lack of appropriate technical skills and knowledge (Pan et. al., 2004), and it is difficult to attract new workers and train them with new IBS skills (Blismas and Wakefield, 2009). Deficiency in skills and knowledge resulted to improper assembly of the components (Kamar et. al., 2009), which, will affect the end product qualities. Moreover, it requires more time and investment to provide intensive training to the workers (Nawi et. al., 2011). On the other hand, the usage of the machinery and equipment faced the problems with limited movement around the site (Blismas et. al., 2005). At the same time, it is difficult to obtain equipment and machinery to carry out the tasks (Kamar et. al., 2007).

In essence, IBS components not only produced in the factory but also can be produced in a large scale at the construction site which will lead to cost savings in terms of transportation. However, due to the space constraint, the on-site casting yard cannot be realized (Jaillon and Poon, 2009). Practically, producing a large scale IBS component normally been carried out off-site which required transportation medium in shifting the components of the production site to the construction site. Great planning is crucial in estimating the delivery time of IBS components to ensure it is in-line with the preparation of the site. Otherwise, the components will expose to the risk of damage, especially when the components are not properly stored. Damage to IBS components on-site will give greater implication to cost, time and process compared to traditional construction materials (Pasquire and Gibb, 2002). Other problems in relation to transportation are that the limit for large component due to items' mass, road widths, bridge load capacity and transport curfews (Blismas and Wakefield, 2009). Most of the IBS manufacturers and factory located in west peninsular Malaysia. Thus, it results to ineffective distance to a site, which located far from the manufactured location. Weather problem can be eliminated once IBS method applied in construction operation (Thanoon et. 
al., 2003). However, this benefit gained from the production of IBS in a factory only. Transportation and installation activities still affected by extreme weather condition (Kamar et. al., 2009).

One of IBS characteristics is component standardization in building (Gibb and Isack, 2001), yet this characteristic has coupled with technical challenges during installation such as low interfaces tolerances in between components (Blismas and Wakefield, 2009). Other problems as explained by Onyeizu et. al., (2011) include interfaces between new and existing construction, joints between difference module or components and electrical connection between factory made product and site-installed. Therefore, the contractor requires to have more understanding in coordinating the complex interfacing issue, failure to deal with this complexity will reduce the quality of the completed building. On the other hand, Thanoon et. al., (2003) stated that IBS is flexible in terms of design and construction, but Sadafi et. al., (2011) highlighted that IBS usage faced the problem of the difficulties in applying changes in the middle of site work and over its life span.

Improving quality is one of the benefits achieved by using IBS (Goodier, 2012). However, this benefit offset by poor quality of IBS components while reaching on-site (Kamar et. al., 2007), this might due to the production fault, transportation and handling. At the same time, the contractor is faced with the difficulties during installation at the site in order to comply with the design and manufacturing requirement (Lou and Kamar, 2012). Therefore, to ensure this benefit materialize, it requires strict quality control and close monitoring during the process (Mohamad et. al., 2009).

Another challenge that the contractor need to consider is to enhance the cooperation with manufacturers and suppliers which is currently weak (Kamar et. al., 2009), as IBS construction itself required close integration and cooperation among stakeholders (Hamid et. al., 2011). Moreover, when large proportions of works are carried out off-site, the contractor has the potential for loss of management control (Blismas and Wakefield, 2009).

\subsection{Post-construction phase.}

The completed product during this phase portrayed the effectiveness of IBS implementation. However, there are still cases where building projects constructed using IBS is poor in quality (CIDB, 2010). Amongst the factors that contribute to the poor quality of IBS buildings are defects which resulting from inadequate technical knowledge, shoddy workmanship and poor quality control which causes aesthetic and functional faults (Pan et. al., 2012). The defects include cracks, blemishes, moisture penetration, water leakage due to improper jointing and poor thermal insulation (Onyeizu et. al., 2011). Defects during the handover period will cause further maintenance problems in the future (Wong et. al., 2003). Thus, the benefits of IBS implementation in-terms of reduction in defects simultaneously producing quality building cannot be gained if the root of this challenge is not properly overcome. The identified challenges were then summarised according to the construction phases as illustrated in Figure 2. 


Pre-construction
- High initial cost
- Huge volume of work to break even
- Lack of equipment \& machinery,
testing facility \& IBS components
- Insufficient knowledge about
building materials and their
installation systems
- Lack of integration between project
team
- Difficulties of planning
- Lack of knowledge among designer
- The processes employed to
construct a facility influence the
project duration
- Conversion of conventional drawing
to IBS drawing
- No standard design or guidelines for
the product
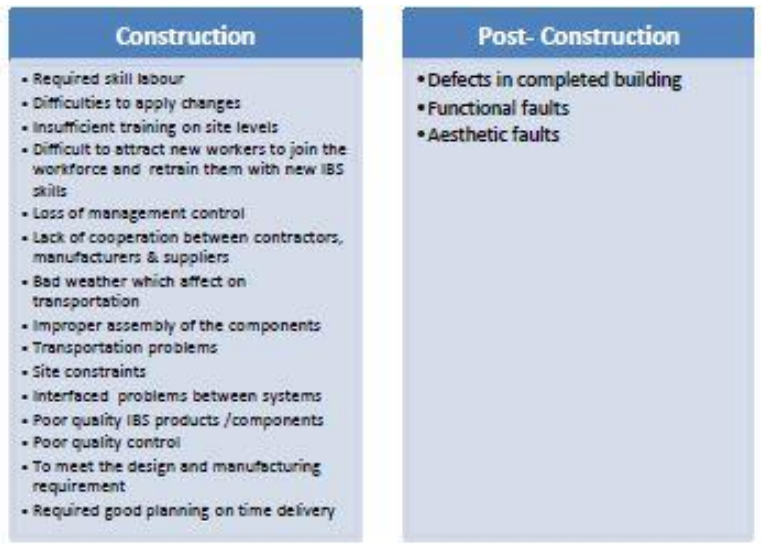

Figure 2: Categorization of IBS Issues

\subsection{Conclusion}

Literature research shows that there are 28 challenges concerning of project management in the IBS construction project. The challenges can be divided into three categories, namely; pre-construction, construction and post-construction phase. Most of the challenges that need critical attention by the contractor are under construction phase. The majority of the challenges were in this category due to the involvement of many parties during the construction phase. Besides that, construction phase usually has a longer duration compared to the other two phases, thus increase the number of issues arises. Categorizing the challenges will help to increase the contractor's understanding and help them to be prepared in handling the situation that they might face during the construction process. Properly manage the challenges will further reduce difficulties such as delays, poor qualities of the final product and cost overrun.

\section{References}

Aburas, H. (2011). Off-Site Construction in Saudi Arabia: The Way Forward. Journal of Architectural Engineering, 17(4), 122. doi:10.1061/(ASCE)AE.1943-5568.0000048

Alinaitwe, H. M., Mwakali, J., \& Hansson, B. (2011). Assessing the degree of industrialisation in construction - a case of Uganda. Journal of Civil Engineering and Management, 37-41.

Arif, M., \& Egbu, C. (2010). Making a case for offsite construction in China. Engineering, Construction and Architectural Management, 17(6), 536-548. doi:10.1108/09699981011090170

Blismas, N., \& Wakefield, R. (2009). Drivers, constraints and the future of offsite manufacture in Australia. Construction Innovation, 9(1), 72-83. doi:10.1108/14714170910931552 
Chong, L. P. (2006). Implementation Strategy For Industrialised Building System.University Teknologi Malaysia

CIDB. (2011). The Current State of Industrialized Building System (IBS) Construction in Malaysia: Drivers, Barriers and The Way Forward. Proceedings of 1st IBS Roundtable Workshop. CIDB.

Hashim, M. S., \& Kamar, K. A. M. (2011). Experiences and Lesson Learnt on IBS Construction in Malaysia. Industrialized Building System (IBS): Definition, Concept and Issues.

Idrus, A., Hui, N. F. K., \& Utomo, C. (2008). Perception of Industrialized Building System (IBS) Within the Malaysian Market. International Conference on Construction and Building Technology, ICCBT2008, (07), 75-92.

Ismail, F., Ahmad, N., Janipha, N. A. I., \& Ismail, R. (2012). The Behavioural Factors' Characteristics of safety culture. Journal of Asian Behavioral Studies, 2(4), 67-75.

Jabar, I. L., Ismail, F., Aziz, N. M., \& Janipha, N. A. I. (2013). Construction Manager's Competency in Managing the Construction Process of IBS Projects. In Procedia - Social and Behavioral Sciences (Vol. 105, pp. 85-93). Elsevier B.V. doi:10.1016/j.sbspro.2013.11.010

Jabar, I. L., Ismail, F., \& Mustafa, A. A. (2013). Issues in Managing Construction Phase of IBS Projects. In Procedia - Social and Behavioral Sciences (Vol. 101, pp. 81-89). Elsevier B.V. doi:10.1016/j.sbspro.2013.07.181

Jaillon, L., \& Poon, C. S. (2009). The evolution of prefabricated residential building systems in Hong Kong: A review of the public and the private sector. Automation in Construction, 18(3), 239-248.

Kamar, Kamarul Anuar Mohd, Kamar, M., Abd, Z., Maria, H., Mohd, Z., Ahmad, Z., Abd, H., et al. (2012). Drivers and barriers of industrialized building system (IBS) roadmaps in Malaysia. Malaysian Construction Research Journal, 9, 1-8.

Lou, E. C. W., \& Kamar, K. a. M. (2012). Industrialized Building Systems: Strategic Outlook for Manufactured Construction in Malaysia. Journal of Architectural Engineering, 18(2), 69-74.

Nadim, W., \& Goulding, J. S. (2010). Off-site production in the UK: the way forward? A UK construction industry perspective. Construction Innovation: Information, Process, Management, 10(2), 181-202.

Nawi, M. N. M., Lee, A., \& Nor, K. M. (2011). Barriers to Implementation of the Industrialized Building System (IBS) in Malaysia. The Built \& Human Environment Review, 4, 22-35.

Onyeizu, E. N., Hassan, A., \& Bakar, A. (2011). The Utilization of Inustrialised Building System in Design Innovation in Construction Industry. Applied Sciences, 15(2), 205-213.

Pan, W., Gibb, A. G. F., \& Dainty, A. R. J. (2012). Strategies for Integrating the Use of Off-site Production Technologies in Housebuilding. Journal of Construction Engineering and Management.

Pasquire, C. ., \& Gibb, A. G. F. (2002). Considerations for assessing the benefits of standardisation and preassembly in construction. Financial of Management of Property and Construction., 7(3).

Rahman, A. B. A., \& Omar, W. (2006). Issues and challenges in the implementation of industrialized building systems in Malaysia. Proceedings of the 6th Asia-Pacific structural Engineering and Construction Conference (Apsec 2006), Kuala Lumpur. Malaysia (pp. 5-6).

Thanoon, W.A, Kadir, M. R. A., Jaafar, M. S., \& Salit, M.(2003). The essential characteristics of industrialised building system. International Conference on Industrialised Building System KL. 